\title{
DETERMINANTS OF WINE CONSUMPTION OF U.S. CONSUMERS: AN ECONOMETRIC ANALYSIS
}

\author{
Mahmood Hussain, Ph.D. \\ Assistant Professor of Marketing \\ Richard Castaldi, Ph.D. \\ Professor of Strategic Management \\ Susan Cholette, Ph.D. \\ Assistant Professor of Decision Sciences \\ College of Business \\ San Francisco State University \\ 1600 Holloway Avenue \\ San Francisco, CA 94132, U.S.A.
}

Contact: Mahmood Hussain, Ph.D.

Email (preferred) hussain@sfsu.edu

Phone: 1-415-338-6290

Fax: 1-415-338-0501 


\title{
DETERMINANTS OF WINE CONSUMPTION OF U.S. CONSUMERS: AN ECONOMETRIC ANALYSIS
}

\begin{abstract}
The U.S. is predicted to be the largest wine consumer by 2008. The driving forces of globalization have significantly altered the competitive landscape of wine industry. While the demand for wine in the U.S. is growing, U.S. wineries continue to lose domestic market share. In order to counter foreign competition as well as grow in this volatile environment, they must evolve by adopting a stronger market orientation. That is, consumers should be at the core of any plan. This shift in orientation requires a solid understanding of consumption behavior of wine drinkers in the U.S. To this end, this paper offers a fresh perspective on the consumption behavior of wine drinkers in the U.S. In this study, we estimate econometrically the determinants of wine consumption. One of the goals of this study is also to provide a roadmap to identify and quantify determinants of wine consumption by employing an econometric procedure called Categorical Regression Estimation for non-numeric response variables. In empirically testing such effects, we used 122 survey responses and found significant positive relationship between knowledge and consumption of wine. Although age and race appear to influence consumption of wine, knowledge remains the most important determinant in wine consumption. The results imply that U.S. wineries need to better educate and connect with consumers by developing compatible positioning strategies and marketing programs that are as informative as entertaining. The results provide further managerial and theoretical implications and directions for future research addressing consumption behavior of drinkers in the U.S.
\end{abstract}

Keywords: Wine marketing, consumer behavior, categorical regression, wine consumption.

\section{INTRODUCTION}

The U.S. is currently the third largest nation in terms of total wine consumption and is predicted to become the largest by 2008 (Packard, 2006). In 2003, demand for wine grew for the $10^{\text {th }}$ straight year in the United States. Per capita consumption of wine reached almost 11 liters per adult in 2003. Recent gains in wine consumption can be attributed in part to the adoption of wine in early adulthood by the millennial generation (Heeger, 2006) and to the oversupply of grapes which made possible the introduction of extreme value wines. With the rise in per capita income in the U.S., the demand for higher quality food and beverages is expected to rise in the coming years (Wine Market Council, 2003). According to a recent survey conducted for the Wine Market Council, the percentage of "core" consumers, who drink wine at least once a week, has grown $38 \%$ since 2000 (Penn, 2006).

\section{U.S. Supply and U.S. Demand: A Mismatch}

Although the nation's demand for wine is strong, the U.S. imports more wine and wine products than it exports (Figure 1). In 2002 the total value of imported wine and related products was $\$ 2.7$ billion and rose to $\$ 3.1$ billion in 2003. Between 2000 and 2003, imports of wine into the U.S. grew more rapidly than its exports, resulting in widening trade deficit, shown in Figure 
1. Revenues of U.S. wineries grew in absolute terms, indicating either expansion of consumer base or increased wine consumption of existing consumers. However, these wineries are losing consumers in relative terms. That is, their domestic market share is eroding in the face of intense competition from foreign wines. The majority of imports came from France, Italy, Australia, and Chile with Australia's market share growing at the fastest rate. Between 1995 and 2003 share of imported wine as a percent of total wine purchased in the U.S. grew from $13 \%$ to $20 \%$. In summary, sales of domestic wine in the U.S. have remained nearly flat, while sales of imported wines have continued to grow.

Figure 1: United States Wine Imports, Exports, and Balance of Trade: 2000-2003

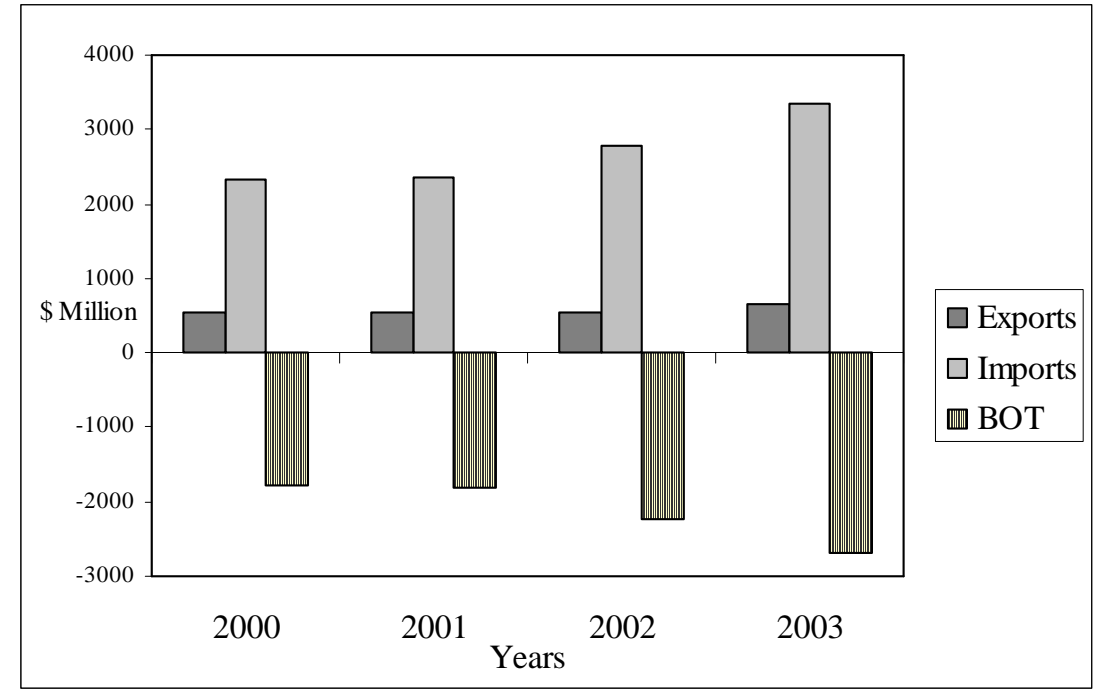

Source: California Wine Export Program (2003).

Historically, US wineries adopted either of three orientations - lifestyle, product, or production. They are in the wine business because they love making wine (lifestyle), or they know how to produce high quality wine (product) or more of it at lower costs (production). In essence, customers were not the starting point of their marketing plans and activities. However, in a globalized wine market the core advantage must be complemented by an understanding of their current and potential customers. Market driven companies base their production and distribution plan on a clear understanding of consumers' needs.

Even today a consumer is expected to invest time, attention and energy into becoming knowledgeable about wine in order to make sense of and select from among the numerous choices on a store shelf. "The traditional wine education approach has been and continues to be 'a bridge too far' for the uninvolved. The vast majority of wine consumers just want to be able to buy a bottle of wine they will like every time, without having to take classes in Ito calculus or theoretical physics in French" (Stallcup, 2005). Wine producers positioned wine as something to be exclusive and consumed only by knowledgeable consumers in a very formal setting. Apart from this historical inertia of U.S. wineries to focus primarily on consumers, external forces also impacting wine business in significant ways. 
Three driving forces have recently caused sweeping changes in the competitive structure and business model used in the wine industry (Cholette et al., 2005). These forces are: (i) worldwide over supply of grapes and incumbent pricing pressure, (ii) consolidation of wine producers, distributors, and retailers, and (iii) shifting consumer behavior patterns. Not surprisingly, consolidation of the wine business was a major topic in the 2006 Unified Wine and Grape Symposium. Despite consolidation the U.S. wine industry remains quite fragmented unlike other consumer goods sector and is unable to exert much price control over their products (Franson, 2006). The fragmented nature of the wine sector translates into the need for greater marketing efforts by wineries. They must tailor their education of customers in a manner that is relevant to customers' needs and lifestyles. Only then will they be able to better attract consumers as well as build a loyal base, from which they can command a price premium for their wines.

Above all, the ever increasing threat from foreign competition looms, an inexorable consequence of the rapid globalization of virtually every sector of the U.S. economy. Australian wines, not domestic wines, are drawing more Millennials, drinkers between the age of 21 and 28 (Heeger, 2006). Adding to the woes of U.S. wineries, most American consumers perceive Californian wines as non-unique compared to wines from France, Italy, and Australia. Australian wine manufacturers have mastered the techniques of branding. Consequently, they have been able to draw a significant portion of generation millennial drinkers to their wines. In order to maintain and expand their market share, U.S. wineries must concentrate on selling what the consumers need and want. This shift in orientation toward the marketplace warrants a clear understanding of the consumer characteristics that determine their wine consumption behavior. In essence, wine producers need to adopt a market orientation.

Market orientation is a philosophy that emphasizes company-wide generation of market intelligence concerning current as well as potential customers and competitors, dissemination of this intelligence within the organization, and reactive as well as proactive responsiveness to the intelligence (Kohli and Jaworski, 1990). Interested readers may consult Bruwer et al (2002) for a thorough discussion on the need for these wineries to adopt a market orientation, especially with respect to understanding U.S. wine consumers. Wine Producers need to begin by asking questions, such as who their customers are, what their motivations are for consuming wine, how they make decision about and purchase of wine; what are the attractions of imported wines compared with U.S. wines, how to create a pleasant experience for these drinkers, and how they can convert them into their loyal customers.

\section{Significance of the Study}

Compared with prior research in the area of wine marketing, our research differs in significant ways. Extant academic literature has focused primarily on the globalization of wine industry and its implications for the U.S. wine industry (Cholette et al., 2005; Castaldi et al., 2004; Silverman et al, 2003). There have been quite a few rigorous academic studies of wine consumers in Australia and New Zealand, such as Bruwer et al, (2002); Thomas and Pickering, (2003); Johnson and Bruwer, (2003). These papers employ various segmentation techniques to enhance their understanding of domestic consumers as well as provide important 
recommendations for their domestic producers. However, there has been a severe paucity of econometric analysis of the determinants of consumption behavior of U.S. wine consumers.

Only recently have studies appeared that aimed for a greater understanding of wine drinkers in the U.S. In an empirical study that uses responses from 108 echo boomers, also known as the millennium generation, Thach and Olsen (2005) describe the perception and attitude of these drinkers. Another study sponsored by Constellation Wines mapped a segmentation of U.S. wine drinkers. The study found that premium wine consumers in the U.S. can be categorized into six segments: enthusiast, image seeker, savvy shopper, traditionalist, satisfied sipper, and overwhelmed (Constellation Wines 2005). Although the Constellationdriven study is the largest segmentation study of its kind, it is a nonacademic study, specifically tailored to meet needs of that particular conglomerate. Thus it may not offer relevant implications for smaller wineries, which are in dire need of understanding and connecting with American consumers. Therefore, it is not surprising for researchers in the area of wine marketing to express the need for an in-depth consumer study: "the ideal study would tie self-reported consumer behavior with their purchases, so demographic information and additional purchase behavior history could be collected" (Cholette and Castaldi, 2005). In that sense, this study fills a void by incorporating a detailed econometric analysis of consumers. It offers a fresh and rigorous perspective on the consumption behavior of wine drinkers in the U.S. It is one of the very few U.S. focused academic studies that employs econometric procedure to analyze the determinants of wine consumption of U.S. drinkers. The findings and their implications can be a source of marketing recommendations for the U.S. wineries and for designing future studies of greater magnitude.

\section{RESEARCH METHODOLOGY}

The study presents a statistical description of wine consumers as well as an econometric analysis of the determinants of their wine consumption. Data on consumer characteristics and wine consumption were collected by a survey through. Owing to certain resource and time constraints, we adopted a non-probabilistic sampling method to draw samples. That is, respondents were contacted at convenient locations, such as, campus and financial district in a Northern California city. Eventually, we collected 122 completed surveys from consumers in Northern California. The questionnaire used close-ended, multiple-choice questions to obtain information on certain demographic variables (age, gender, income, occupation, race), as well as behavioral variables (uses, benefits, influences, consumption volume, expenditure on wine), and knowledge level related to wine consumption. Using these data, we develop and empirically test a model where various dimensions of consumers determine the consumption of wine. We do not provide formal hypotheses but explain and empirically explore how different characteristics of a consumer influence wine consumption.

\section{Econometric Framework: Categorical Regression (CATREG)}

One of the goals of this study is to provide a roadmap to derive determinants of wine consumption by illustrating an econometric procedure called Categorical Regression Estimation (CATREG) for non-numeric variables. CATREG has been recently used in behavioral, social science, and medical studies that uses response data to estimate a behavioral model, as used in 
Liyanarachchi and Theivananthampillai, (2005); Zhang, (2002); and Haber et al., (2001). It does not rely on the stricter assumptions associated with multiple regression, and specifically allows the inclusion of ordinal or multi-categorical data (SPSS, 2005; McNamara et al., 2005). Since most of the explanatory variables used in this analysis are non-numeric variables, we employed CATREG with optimal scaling in SPSS. It is a special variant of regression which is useful when there is a combination of nominal, ordinal, and interval-level independent variables. It is a utilitarian multiple regression of variables that may require to be optimally scaled prior to being used in econometric analysis. Its optimal scaling property converts categorical variables into numerical variables to find the best model fit. That is, CATREG maximizes goodness of fit by finding appropriate values for categorical variables (Garson, 2001). Also, to find the relative importance of explanatory variables, CATREG is preferred to other methods. In short, CATREG offers more flexibility by simultaneously scaling nominal, ordinal, and numerical variables. In order to verify the robustness of CATREG results, we augment the CATREG results by applying Ordinary least Squares (OLS) regression.

The difference between CATREG and OLS can be summarized as follows. First, in OLS parameters estimates and the constant are estimated directly. CATREG transforms and standardizes non-numerical variables into numerical variables prior to estimation. Since it then estimates standardized coefficients in an iterative fashion, it omits the constant. As a consequence, the sums of squares presented in ANOVA tables of CATREG and OLS are different (WebRAFT, 2006). More details on CATREG can be found in various SPSS manual (SPSS, 2005). Also, CATREG yields only standardized coefficient estimates, whereas OLS reports both non-standardized and standardized coefficient estimates.

\section{EMPIRICAL FINDINGS}

\section{Sample Characteristics}

The sample size of 122 , which is evenly split between men and women, covers participants from all age groups ranging from mid 20 s to over 60 years. We also observe a wide variation in respondents' incomes which ranges from below U.S. $\$ 20,000$ to more than U.S. $\$ 100,000$. On average, the respondents were relatively young (34 years of age) with $65 \%$ of them falling in the 25-34 age group. Most of the 122 respondents surveyed are financially affluent, as indicated by the average annual personal income of U.S. $\$ 56,000$. Almost half (47\%) indicate having an annual personal income of U.S. $\$ 70,000$ or more. A large portion of these respondents are single $(63 \%)$, professionals who are employed in various private and non-private sectors $(68 \%)$, and white $(66 \%)$. Students accounted for only $32 \%$ of the respondents.

\section{Wine Consumption Behavior}

Here we examine descriptive statistics and pair-wise correlations between selected variables. In order to ensure a clear interpretation of correlation coefficients and subsequent results, we define the variable value (ordinal or nominal) in Table 1. For the sake of brevity a complete definition of these variables are skipped in this paper. The partial correlation coefficients and their statistical significances are shown in Table 2. The signs of the correlations 
appear to be consistent with expected relationships, though these correlations do not necessarily imply causality. For example, Table 2 indicates that knowledge of wine and consumption are positively and significantly correlated. The same can be said of the pair-wise relationships between consumption-age and consumption-income. Positive and significant relationship between age and income also agrees with the conventional wisdom (that is, with age we acquire more skills and education which results in higher income). Since other variables are nominal in nature, we exercise caution at this point by not making any claim on their statistical correlation.

Table 1: Variables and Their Codes Used in the Regression Analysis

\begin{tabular}{|c|l|c|c|c|c|c|r|}
\hline Levels & Knowledge & $\begin{array}{c}\text { Age } \\
\text { (years) }\end{array}$ & Gender & $\begin{array}{c}\text { Marital } \\
\text { Status }\end{array}$ & \multicolumn{1}{|c|}{ Profession } & Race & $\begin{array}{c}\text { Income } \\
\mathbf{( ' 0 0 0} \mathbf{\text { } )}\end{array}$ \\
\hline 1 & Clueless & $21-24$ & Male & Single & Private Industry & Caucasian & $0-20$ \\
\hline 2 & Little & $25-34$ & Female & Married & Self-employed & African American & $20-40$ \\
\hline 3 & Somewhat & $35-44$ & - & Divorced & Government & Asian/Pacific & $40-60$ \\
\hline 4 & Knowledgeable & $45-54$ & - & - & Non-profit & Hispanic & $60-80$ \\
\hline 5 & Expert & $55-64$ & - & - & Student & - & $80-100$ \\
\hline 6 & - & $64+$ & - & - & - & - & $100+$ \\
\hline $\begin{array}{l}\text { Optimal } \\
\text { Scaling }\end{array}$ & Ordinal & Ordinal & Nominal & Nominal & Nominal & Nominal & Ordinal \\
\hline
\end{tabular}

Source: Survey data

Table 2: Pearson Correlations between Variables Used in the Regression Analysis

\begin{tabular}{|c|c|c|c|c|c|c|c|c|}
\hline Variables & $\begin{array}{c}\begin{array}{c}\text { Consump- } \\
\text { tion }\end{array} \\
\end{array}$ & $\begin{array}{l}\text { Know- } \\
\text { ledge }\end{array}$ & Age & Gender & Income & $\begin{array}{c}\text { Marital } \\
\text { Status }\end{array}$ & $\begin{array}{l}\text { Profe- } \\
\text { ssion }\end{array}$ & Race \\
\hline Consumption & 1 & & & & & & & \\
\hline Knowledge & $0.59(* *)$ & 1 & & & & & & \\
\hline Age Group & $0.24(* *)$ & 0.18 & 1 & & & & & \\
\hline Gender & 0.100 & 0.11 & -0.03 & 1 & & & & \\
\hline Income group & $0.27(* *)$ & 0.17 & $0.36(* *)$ & 0.10 & 1 & & & \\
\hline Marital status & $0.22(*)$ & 0.15 & $0.41(* *)$ & 0.03 & $0.57(* *)$ & 1 & & \\
\hline Profession & $-.031(* *)$ & $-0.22(*)$ & $-0.27(* *)$ & 0.02 & $-0.56(* *)$ & $-0.28(* *)$ & 1 & \\
\hline Race & $-0.22(*)$ & -0.14 & -0.02 & -0.14 & -0.07 & -0.07 & 0.13 & 1 \\
\hline
\end{tabular}

Source: Survey data

Table 3 compares means of selected variables by consumption volume. The range of mean values indicates that there is enough variability in the measures of the major constructs. We see a strong presence of both light (1-6glasses/month) and heavy (13+ glasses/month) drinkers. It is noteworthy that this definition of light versus heavy drinker is somewhat arbitrary and a slight change in the definition does not modify the findings of the research. The reason being, we have used consumption (glasses per month) as a continuous variable which is not subject to optimal scaling in CATREG. As expected, knowledge and income are, once again, found to be positively related with wine consumption. The mean scores for knowledge range from 1.36 for non-drinkers to 2.94 for heavy drinkers. It is also interesting to note that $20 \%$ (i.e., 25 of 122) of the survey respondents, are self-reported to be non-drinkers of wine, appear to be mostly younger consumers, possibly indicating the lack of interest in wine by the Generation $\mathrm{X}$ 
consumers. This figure may be indicative of yet another untapped opportunity for U.S. wineries. They could appeal to the palate of these younger consumers by devising positioning strategies and marketing programs that are well anchored to an understanding of consumers' needs and motivations.

Table 3: Relationship between Consumption and Selected Variables (Mean)

\begin{tabular}{|c|c|c|c|c|c|c|c|c|c|c|}
\hline \multirow{2}{*}{$\begin{array}{l}\text { Glasses } \\
\text { per month }\end{array}$} & \multirow{2}{*}{ Count } & \multicolumn{3}{|c|}{ Mean } & \multicolumn{6}{|c|}{$\begin{array}{c}\text { Price category (per } 750 \mathrm{ml} \text { bottle) - } \\
\text { average \# of bottles bought }\end{array}$} \\
\hline & & $\begin{array}{l}\text { Know- } \\
\text { ledge }\end{array}$ & Age & $\begin{array}{l}\text { Income } \\
(\$)\end{array}$ & $\begin{array}{l}\$ 5 \text { or } \\
\text { less }\end{array}$ & $\$ 5-10$ & $\$ 10-15$ & $\$ 15-30$ & $\$ 30-50$ & $\begin{array}{c}\$ 50 \text { or } \\
\text { over }\end{array}$ \\
\hline 0 & 25 & 1.36 & 29 & 42,800 & - & - & - & - & - & - \\
\hline $1-6$ & 46 & 2.04 & 32 & 53,478 & 2.85 & 2.59 & 2.20 & 1.43 & .87 & .37 \\
\hline $7-12$ & 16 & 2.75 & 37 & 59,375 & 3.31 & 8.06 & 5.56 & 5.50 & 1.13 & .31 \\
\hline $13+$ & 35 & 2.94 & 34 & 67,428 & 18.00 & 21.40 & 11.54 & 4.54 & 1.26 & .46 \\
\hline \multicolumn{2}{|c|}{ Grand Mean } & 2.25 & 33 & 56,065 & 6.70 & 8.50 & 4.96 & 2.61 & .84 & .31 \\
\hline
\end{tabular}

Table 3 also shows a relationship between knowledge of wine and consumption of wine. However, this overarching linear relationship between knowledge and consumption masks an important phenomenon that wine consumers seek variety. As to the relationship between expenditure and consumption, Table 2 reinforces the variety-seeking nature of wine consumers (Cholette and Castaldi 2005). The consumers are indeed variety-seeking, with their spending on wines spreading over different price points and consumption volumes and mostly concentrated around inexpensive to mid-priced wines. Figure 2 provides yet another example of variety seeking behavior. We plot percentage of wine purchases in each price category on the vertical axis and arbitrarily selected price category of wines on the horizontal axis. Different lines in Figure 2 represent wine consumers with different level of knowledge ( 1 being "clueless" and 5 being "most knowledgeable" or "expert"). It is noteworthy that this categorization is selfreported and none of the respondents categorized themselves as an "expert."

Figure 2: Wine Consumers: Variety Seeking Behavior (Knowledge vs. Purchases)

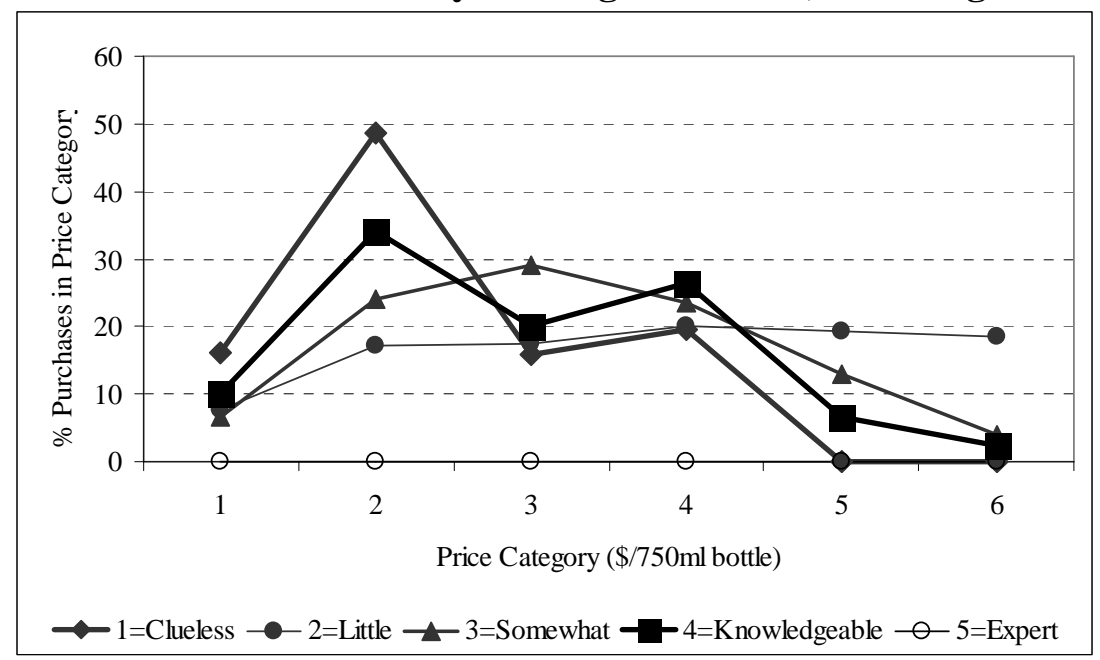

Source: Survey data 
Figure 2 portrays a very interesting picture of consumers' variety seeking behavior. "Clueless" consumers seem to gravitate toward cheaper wine, although they do not mind to occasionally spend on expensive wines. Their ignorance of wine may preclude them from spending any more than $\$ 50$ per $750 \mathrm{ml}$ bottle. On the contrary, consumers with both "little" and some knowledge appear to follow a normal pattern. That is, most of their expenditure on wine is concentrated around the mid priced (\$10-30) wines with occasional consumption of both inexpensive and expensive wines. On the contrary, knowledgeable consumers follow a bimodal pattern of wine consumption - drinking a lot of both cheaper and pricier wines. From a crossvariable analysis (results not presented here) we conjecture that their choice for both inexpensive and expensive wines depend on such factors as previous experience, origin, and choice of company (friends or relatives) with whom they prefer to drink wine.

\section{Regression Results}

In a highly competitive market, characterized by rapidly evolving driving forces, it is imperative for wine marketers to employ effective marketing strategies. One starting point is to examine the underlying consumer characteristics and their impact on the consumption behavior of wine drinkers. In this section, we determine econometrically which consumer characteristics are most important and to what extent they can explain wine consumption. Table 4 summarizes the results of CATREG analysis. The first two columns display variables and their scales used in the regression.

As noted earlier, CATREG is suitable for finding the best fit for a model with a combination of non-numerical variables. Columns 5 through 7 present the $\mathrm{R}^{2}, \mathrm{~F}$-value, and significance of the CATREG model. The $\mathrm{R}^{2}$ of 0.35 , indicating that almost $35 \%$ of the variance can be explained by the regression of optimally transformed non-metric predictors, seems a reasonably acceptable predictor in the marketing literature. Additionally, the standardized coefficients of knowledge, age, and race ( 3 of 7 predictors), with corresponding F statistics and P-values, indicate they exert statistically significant influence on wine consumption.

Table 4: Categorical Regression Coefficients

Dependent Variable: Glasses of Wine Consumed per Month

\begin{tabular}{|c|c|c|c|c|c|c|c|}
\hline \multirow{2}{*}{ Variables } & \multirow{2}{*}{ Scale } & \multicolumn{2}{|c|}{$\begin{array}{r}\text { Standardized } \\
\text { Coefficients }\end{array}$} & \multirow{2}{*}{ F-value } & \multirow{2}{*}{$\begin{array}{c}\text { Significance } \\
\text { (P-value) }\end{array}$} & \multirow{2}{*}{$\mathbf{R}^{2}$} & \multirow{2}{*}{$\begin{array}{l}\text { Importance } \\
(\text { Sum }=1.00)\end{array}$} \\
\hline & & Beta & Std. Error & & & & \\
\hline Knowledge & Ordinal & 0.39 & 0.10 & 16.31 & 0.00 & \multirow{7}{*}{0.35} & 0.54 \\
\hline Age & Ordinal & 0.24 & 0.11 & 5.14 & 0.00 & & 0.18 \\
\hline Gender & Nominal & 0.04 & 0.10 & 0.15 & 0.70 & & 0.01 \\
\hline Marital status & Nominal & 0.11 & 0.10 & 1.36 & 0.26 & & 0.00 \\
\hline Professional & Nominal & -0.08 & 0.11 & 0.50 & 0.78 & & 0.00 \\
\hline Race & Nominal & -0.23 & 0.10 & 5.15 & 0.00 & & 0.22 \\
\hline Income & Ordinal & 0.10 & 0.10 & 1.00 & 0.32 & & 0.05 \\
\hline
\end{tabular}

Knowledge and age seem to have strongest influence on wine consumption. Table 1 already showed how CATREG, prior to the regression, quantified race, originally a nominal 
variable. As noted, the CATREG assigned Whites a value of 1 , while non-whites received higher values (2-4 for African American, Asian, Hispanic respondents respectively). Thus, the result implies that a non-white a drinker is likely to consume less wine consumption than her white counterpart. Considering a snapshot of today's wine consumers, this prediction appears to be congruent with the reality. At this point, we must note with caution that this reality seems to be rapidly changing with growing importance of other markets, especially Hispanic consumers (Jung, 2005). The static nature of regression does not allow us to make further comments on the relationship between race and wine consumption. In order for us to be able to make prediction on the dynamics of wine market the regression analysis needs to include data from a panel (a combination of cross-sectional and time-series data).

Although it is tempting to overemphasize the coefficients of knowledge, age, and race, the standardized coefficients (Beta) cannot fully explain the impact of these predictors since the original variables were transformed. Therefore, CATREG reports the measures of relative importance that are useful to further explore the relative importance of explanatory variables (Pratt, 1987). The final column of Table 3 displays the importance these variables knowledge stands out as the most important explanatory variable, followed by age and race.

Figure 3 shows graphically the relative importance of the different explanatory variables presented in Table 3. The level of knowledge plays an important role in determining consumers' involvement in wine purchase (Lockshin et al., 1997). Not surprisingly, the vital role of knowledge in purchase and consumption of wine makes wine purchase behavior a complex issue. As recently as 15 years ago, knowledge of wine was found to cause consumers to drink less but higher quality wine (Spawton, 1991). The findings from the current study, as well as a few other recent studies, indicate that the behavior of wine drinkers may have shifted (Moulton et al., 2001). That is, greater knowledge of wine minimizes confusion about wines as well as enhances emotional attachment which eventually translates into not only choice of high quality wine but also increased consumption. Based on an empirical study that came from a mystery shopper program Olsen and Thach (2005) identifies visitor education as one of the most important factors correlated with emotional attachment. Wine's health benefits, as highlighted in numerous medical studies in the past decade, might also account for this positive influence of knowledge on wine consumption.

Figure 3: Categorical Regression: Relative Importance of Explanatory Variables

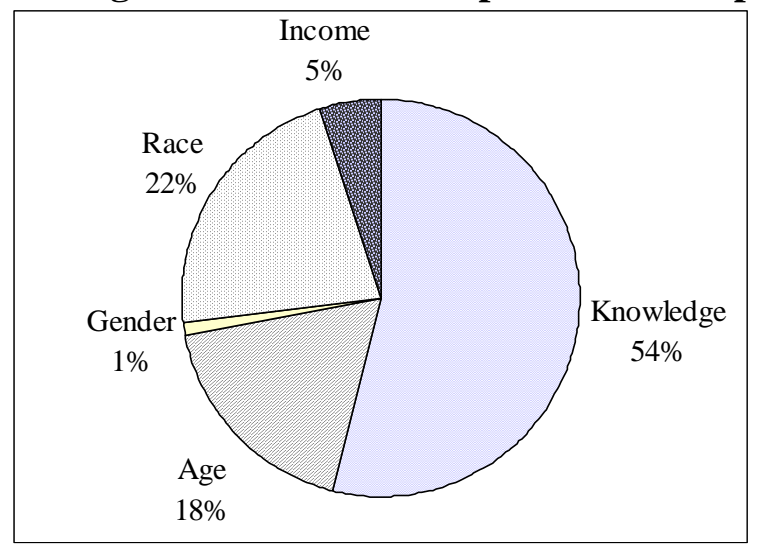


Since CATREG does not allow us to use coefficient estimates for a sensitivity analysis, we augment the CATREG results by producing OLS estimates of their effects. This also helps us examine the robustness of CATREG results. To do this we first transform the nominal variables into simple dummy (binary) variables and apply OLS procedure to derive regular coefficients estimates. Table 5 summarizes the OLS regression results.

Only the coefficient estimates of knowledge and race are statistically significant. We can interpret the coefficients of knowledge and race as follows. For example, an increase in knowledge level from "somewhat knowledgeable" to "knowledgeable" is likely increase monthly wine consumption by almost 3 glasses per month. As to the effect of race, a non-white wine drinker is expected to drink about $1 \frac{1 / 2}{2}$ fewer glasses of wine per month than her white counterpart. Qualitatively they provide exactly the same interpretation as above. In essence, coefficients in Table 5 confirm our findings thus far that knowledge remains to be the most significant predictor of wine consumption. Additionally, for the sample analyzed in the study, race appears to exert some influence on wine consumption. Interestingly, following a transformation of nominal variables into dummy variables, the model fit of OLS $\left(\mathrm{R}^{2}=0.41\right)$ appear to improves over that from CATREG $\left(\mathrm{R}^{2}=0.35\right)$.

Table 5: Ordinary Least Squares (OLS) Regression Coefficients Dependent Variable: of Wine Consumed per Month

\begin{tabular}{|c|c|c|c|c|c|}
\hline \multirow{2}{*}{ Variables } & \multicolumn{2}{|c|}{$\begin{array}{c}\text { Regular } \\
\text { Coefficients }\end{array}$} & \multirow{2}{*}{ T-Value } & \multirow{2}{*}{$\begin{array}{c}\text { Significance } \\
\text { (P-value) }\end{array}$} & \multirow{2}{*}{$\mathbf{R}^{2}$} \\
\hline & B & $\begin{array}{l}\text { Standard } \\
\text { Error }\end{array}$ & & & \\
\hline Constant & -1.40 & 1.80 & -0.78 & 0.44 & \multirow{8}{*}{0.41} \\
\hline Knowledge & $* * * 2.95$ & 0.43 & 6.88 & 0.00 & \\
\hline Age & 0.52 & 0.50 & 1.04 & 0.30 & \\
\hline Gender & 0.27 & 0.81 & 0.33 & 0.74 & \\
\hline Marital Status & 0.42 & 1.03 & 0.40 & 0.69 & \\
\hline Profession & -1.46 & 1.05 & -1.39 & 0.17 & \\
\hline Race & $*-1.40$ & 0.85 & -1.64 & 0.10 & \\
\hline Income & 0.14 & 0.31 & 0.45 & 0.65 & \\
\hline
\end{tabular}

Note: *** Significant at the 0.01 level $\quad *$ Significant at the 0.10 level

Source: Survey data

\section{CONCLUDING COMMENTS}

Despite certain limitations discussed below, our research contributes theoretically to the development of a framework for understanding consumption behavior of wine consumers. From the methodology perspective, we provide a roadmap to employ CATREG method, which is useful given a combination of nominal, ordinal, and interval-level independent variables. The CATREG method is further considered appropriate for measuring relative importance of different predictors. We further verified the robustness of CATREG results by deriving OLS results. In addition, several managerial implications arise for wineries. Translated properly into plans and actions, these implications may help them ensure their survival and growth in a volatile and intensely competitive wine market. First, the findings draw our attention to the significance of a drinker's knowledge of wine. Knowledge of wine significantly influences a consumer's 
involvement in wine purchase and her consumption of wine (Lockshin et al., 1997). In order to make consumers feel comfortable with their choice of wine, wineries must facilitate adequate information and education for the potential drinkers. Wineries must start with a clear understanding of consumers' needs and behaviors and devise appropriate communication strategies in order to help them overcome their knowledge deficiency. This enlightenment is especially critical when consumers "do find wine somewhat intimidating and mysterious" (Heeger, 2006).

The wine industry needs to overcome an enormous challenge when it comes to changing consumer knowledge and impressions around buying and drinking wine. Currently $80 \%$ of wine consumers are either "uninvolved" or uneducated about wine. Consumers feel intimidated by 'wine geek speaks' on wine labels and have trouble remembering which wines they bought and liked. Researchers watching consumer behavior have noticed shoppers appear to be confused during the wine selection process. Customers have expressed that they want to easily and consistently be able to identify the wines they will enjoy without having to solicit personal assistance in the store (Stallcup, 2005; Goulet, 2004).

Our study also found race to have an influence in wine consumption. The results strongly imply that whites and non-whites should not be assumed to have the same consumer behaviors. This information deserves special attention from wineries because the wine consumer demographics are evolving rapidly. Research shows that Latinos have been developing a taste for wine in recent years. In 1998, the percentage of Hispanic adults who consumed domestic table wine was $12 \%$, which jumped to $22 \%$ in 2003. A 2004 survey by the Wine Market Council also asked people if they were drinking more, less, or the same amount of wine as the year before. While wine consumption frequency increased by $11 \%$ among whites, it rose by $31 \%$ among Hispanics (Jung, 2005). This emergence of race-specific consumer groups should prompt the wineries to design appropriate positioning and communication strategies as well as employ innovative marketing programs to attract consumers from different races.

Although the findings of the study provide a solid starting point for more detailed studies of U.S. wine consumers, the generalizability of our findings may be limited for the following reasons. First, the findings may be idiosyncratic to the specific sample we collected in a nonprobabilistic fashion in Northern California. Any future study needs to use random sampling method, cover additional geographic areas, and include a larger sample size to enhance generalizability. Second, the CATREG procedure that we employed in this study can be further validated by examining the consistency with alternative methods such as Nonlinear Principal Components Analysis, Nonlinear Canonical Correlation Analysis, and Correspondence Analysis, all of which can handle non-metric data. Any extension will be more meaningful if it also includes additional variables that connect wine consumers' behavior with different wine related attributes and marketing mix elements. Further research could also include regression analysis of panel data to capture the shifting dynamics of wine market. 


\section{REFERENCES}

Bruwer, Johan, Elton Li, and Mike Reid (2002). Segmentation of the Australian Wine Market Using a Wine-Related Lifestyle Approach. Journal of Wine Research. 13 (3), 217-242.

California Wine Export Program (2003). United States Wine Exports, Imports and Balance of Trade. Retrieved January 2006, from http://www.calwinexport.com/content/Stats\&Research/.

Castaldi, Richard, Armand Gilinsky, and Raymond Lopez. (2004). The Globalization of Beringer Blass Wine Estates. Case Research Journal, 24 (1), 65-92.

Cholette, Susan and Richard Castaldi (2005). Analyzing the US Retail Wine Market Using Price and Consumer Segmentation Models. Second International Wine Marketing Symposium Proceedings (CD-ROM). Sonoma State University, July 8-9.

Cholette, Susan, Richard Castaldi, and April Frederick (2005). Globalization of the Wine Industry: Implications for Old and New World Producers. International Business and Economy Conference Proceedings. January.

Constellation Wines (2005). Constellation Wines U.S. Releases Results of Landmark Consumer Study: Project Genome ${ }^{S M}$ Reveals Much About Premium Wine Consumers' Motivations, Behaviors. Retrieved November 03, 2005 from http://www.cwinesus.com/ProjectGenome.html.

Garson, G. David (2001). Guide to Writing Empirical Papers, Theses, and Dissertations. New York: Marcel Dekker, Inc.

Goulet, Marc (2004). Consumers Want Guidance In Choosing Wine at Restaurants. Retrieved February 15, 2006, from http://www.russellresearch.com/news3.htm.

Haber, Lynne, Judy A. Strickland and Daniel J. Guth (2001). Categorical Regression Analysis of Toxicity Data. Comments On Toxicology. 7(5-6), 437-452.

Heeger, Jack (2006). More Wine Drinkers in U.S. Market, But Aussie Marketing, Not Domestic Brand Names, Draw Younger Consumers. Retrieved January 19, 2006 from http://www.napavalleyregister.com/articles/2006/01/20/features/food_and_wine/iq_3254354.txt.

Johnson, Trent and Johan Bruwer (2003). An Empirical Confirmation Of Wine-Related Lifestyle Segments In The Australian Wine Market. International Journal of Wine Marketing. 15 (1), 533.

Jung, Carolyn (2005). Hispanic Market: New Toast of Wine Industry. Retrieved April 27, 2005 from http://www.hispanicbusiness.com/news/news_print.asp?id=22608.

Kohli, Ajay K. and Bernard Jaworski (1990). Market Orientation: The Construct, Research Propositions, and Managerial Implications. Journal of Marketing. 54 (April), 1-18. 
Liyanarachchi, Gregory A. and Paul S. Theivananthampillai (2005). Accounting students' information disclosure decisions: Is there a need for changing the status quo on disclosure through accounting education? Working Paper \# 03_03/05. Department of Accountancy and Business Law, University of Otago, PO Box 56, Dunedin, New Zealand.

Lockshin, L., Spawton T. and Macintosh G. (1997). Using Product, Brand, and Purchasing Involvement for Retail Segmentation. Journal of Retailing and Consumer Services. 4 (3), 171183.

McNamara, Shaun M., Taylor McLachlan and Gregory A. Liyanarachchi, (2005). Time Budget Pressure and Auditor Dysfunctional Behaviour within an Occupational Stress Model. Working Paper \# 05_12/05. Department of Accountancy and Business Law, University of Otago, PO Box 56, Dunedin, New Zealand.

Moulton, K., Spawton, A., \& Bourqui, M. (2001). Introduction: Consumer Behavior and Marketing Strategies. In K. Moulton \& J. Lapsley (Eds.), Successful Wine Marketing. Gaithersburg, Maryland: Aspen Publication, Inc.

Olsen, Janeen and Liz Thach (2005) The Role of Tasting Rooms in Creating An Emotional Attachment to Wine Brands. Research Abstract, Second International Wine Marketing Symposium Proceedings (CD-ROM). Sonoma State University, July 8-9.

Packard, Simon (2006). U.S. to Become World's Largest Wine Market by 2008, Study Shows. Retrieved January 26, 2006, from http://www.bloomberg.com/apps/news?pid=10000103 \&sid=aqSnkUwnQFSI\&refer=us\#.

Penn, Cyril (2006). U.S. Wine Consumption Keeps Going Up. Retrieved January 19, 2006 from http://www.sfgate.com/cgi-bin/article.cgi?f=/c/a/2006/01/19/WIGJGGOS9V1.DTL.

Pratt, J.W. (1987). Dividing the Indivisible: Using Simle Symmetry to Partition Variance Explained. In T. Pukkila and S. Puntanen (Eds.), Proceedings of the Second International Conference in Statistics (245-260). Tampere, Finland: University of Tampere.

Silverman, Murray, Sanjit Sengupta, Richard M. Castaldi (2003). Improving Export Performance: The Case of the U.S. Wine Industry. Journal of Global Marketing, 17 (1), 45-65.

Spawton, T., (1991). Of wine and live asses: An Introduction to the Wine Economy and State of Wine Marketing. European Journal of Wine Marketing. 25(3), 1-48.

SPSS (2005). SPSS Categories® 14.0, Chicago: SPSS, Inc.

Stallcup, John. (April 2005) Toppling the Wall of Confusion. Wine Business Monthly. 12(4) retrieved from http://www.winebusiness.com/html/MonthlyArticle.cfm?dataId=37561. 
Thach, E. and Olsen, J. (2005). Marketing to Echo Boomers, Second International Wine Marketing Symposium Proceedings (CD-ROM). Sonoma State University, July 8-9.

Thomas, Art and Gary Pickering (2003). Behavioural Segmentation: A New Zealand Wine Market Application. Journal of Wine Research. 14 (2-3), 127-138.

WebRAFT (2006). The University of Melbourne Department of Psychology Webpage. Lecture 8: Categorical Data Analysis 1: Optimal Scaling. Lecture in Advanced Design and Data Analysis Retrieved February 12, 2006, from http://128.250.6.185/512422/pub/lecture\%208/.

Wine Market Council (2003). Wine Market Council Consumer Tracking Study 2003. Retrieved May 10, 2005 from http://www.winemarketcouncil.com.

Zhang, Xiaoyang (2002). The Dynamics of Chinese Consumers: A Case of Shanghai Food Consumption. Journal of International Food \& Agribusiness. 14(1), 47-66. 